\title{
Mercury Concentrations in Bulk Atmospheric Deposition over the Coast of Rio de Janeiro, Southeast, Brazil
}

\author{
Luiz D. Lacerda ${ }^{* a}$, Heloisa Helena M. Paraquetti ${ }^{a}$, Carlos E. Rezende ${ }^{b}$, Luiz Fernando F. Silva ${ }^{a}$, \\ Emanuel V. Silva Filho ${ }^{a}$, Rozane V. Marins ${ }^{a}$ and Mario G. Ribeiro ${ }^{a}$ \\ ${ }^{a}$ Departamento de Geoquímica, Universidade Federal Fluminense, Campus do Valonguinho, 24020-007, \\ Niterói - RJ, Brazil. \\ ${ }^{b}$ Laboratório de Ciências Ambientais, Universidade Estadual do Norte Fluminense, Avenida Alberto Lamego, 2000, \\ 28015-620, Campos - RJ, Brazil
}

\begin{abstract}
As concentrações totais de $\mathrm{Hg}$ foram medidas em amostras de deposição atmosférica total coletadas em três regiões costeiras do Estado do Rio de Janeiro, sudeste do Brasil entre Outubro de 1998 e Dezembro de 1999. Amostras foram coletadas em Campos dos Goytacazes, área agrícola no norte do estado, em Niterói, região urbanizada e industrializada, e em Itacuruçá, um pólo turístico no litoral sul. As concentrações de $\mathrm{Hg}$ em Campos apresentaram uma média de $0,51 \mathrm{ng} \mathrm{L}^{-1}$, variando de 0,07 a 1,01 ng L $\mathrm{L}^{-1}$, e mostraram uma tendência sazonal aparentemente afetada pela queima da cana de açúcar no inverno. Em Niterói, foram medidas as maiores concentrações, com média de $0,73 \mathrm{ng} \mathrm{L}^{-1} \mathrm{e}$ variando de 0,06 a 2,95 $\mathrm{ng} \mathrm{L}^{-1}$, sem padrão de distribuição sazonal definido. Em Itacuruçá, 35\% das amostras apresentaram concentrações menores que o limite de detecção do método $\left(<0,02 \mathrm{ng} \mathrm{L}^{-1}\right)$, com média de $0,24 \mathrm{ng} \mathrm{L}^{-1}$ e variando entre $<0,02$ a $1,04 \mathrm{ng} \mathrm{L}^{-1}$.
\end{abstract}

Total $\mathrm{Hg}$ concentrations were measured in bulk atmospheric deposition from three sampling stations along the Rio de Janeiro State coast, Southeast, Brazil, from October 1998 to December 1999. Samples were collected at Campos dos Goytacazes, an agriculture center at the North coast; Niterói, an industrialized metropolitan area and at Itacuruçá, a tourist town at the South. Concentrations at Campos average $0.51 \mathrm{ng} \mathrm{L}^{-1}$, ranging from 0.07 to $1.01 \mathrm{ng} \mathrm{L}^{-1}$, and showed a seasonal trend, probably affected by burning of sugar cane plantations in winter. At Niterói, concentrations were highest, averaging $0.73 \mathrm{ng} \mathrm{L}^{-1}$ and ranging from 0.06 to $2.95 \mathrm{ng} \mathrm{L}^{-1}$. No pattern of temporal variation was observed and concentration peaks are probably related to industrial emissions. At Itacuruçá, $\mathrm{Hg}$ concentrations were below the detection limit of the method $\left(0.02 \mathrm{ng} \mathrm{L}^{-1}\right)$ in $35 \%$ of the samples, with an average of $0.24 \mathrm{ng} \mathrm{L}^{-1}$ and ranging from $<0.02$ to $1.04 \mathrm{ng} \mathrm{L}^{-1}$.

Keywords: mercury, rain water, atmospheric deposition, Rio de Janeiro coastal region

\section{Introduction}

Atmospheric deposition is a significant source of $\mathrm{Hg}$ to surface environments. The large residence time of $\mathrm{Hg}$ in the atmosphere results in large-scale transport and in the input of significant amounts of $\mathrm{Hg}$ to remote sites through atmospheric deposition. ${ }^{1}$ Since the consume of contaminated aquatic biota is the major pathway of $\mathrm{Hg}$ exposure to humans and $\mathrm{Hg}$ levels in these organisms are directly linked to bulk atmospheric deposition rates, ${ }^{2,3}$ knowing $\mathrm{Hg}$ concentrations in bulk atmospheric deposition is a key step

* e-mail: ldrude@ fortalnet.com.br to model the environmental dynamics and forecast $\mathrm{Hg}$ contamination.

Data on $\mathrm{Hg}$ concentrations in bulk atmospheric deposition abound in the northern hemisphere, but very few studies were published in the southern hemisphere. The few examples are from areas close to industrial sites ${ }^{4}$ or from gold mining areas in the Amazon, ${ }^{5,6}$ which frequently show extreme values. A recent extensive survey by Silva Filho et $a .^{7}$, reported only on the particulate fraction of the atmospheric deposition, which has no direct correlation with contamination of aquatic food webs. Therefore we have designed this study to characterize the range of $\mathrm{Hg}$ concentrations in bulk atmospheric deposition over a gradient of landscapes, from a nearly pristine site, 
which can provide local background concentrations, an intensive agriculture region, to an industrialized metropolitan area. It was not the objective of the present work to study rates of deposition, since daily precipitation volume data do not exist for the sites. However, whenever volume data were available they were used to help interpret the variations in $\mathrm{Hg}$ concentrations and preliminary estimate deposition rates for these areas.

\section{Sampling sites}

Samples were collected in 3 coastal areas of Rio de Janeiro State (Figure 1). The Campos dos Goytacazes site is located at the northern coast in a region poorly industrialized but with extensive sugar cane agriculture, with annual yields from 4.6 to 8.8 million tons. ${ }^{8}$ Pre-harvest burning of sugar cane plantations occurs by the end of autumn to the end of the winter (May to October) during the dry season ${ }^{8}$ and may significantly contribute to atmospheric deposition. Precipitation events are due to cold fronts and average 1,000 mm per year. The Niterói site is located at the Universidade Federal Fluminense, downtown Niterói city, by the Guanabara Bay. The site is surrounded by Rio de Janeiro metropolitan area, which harbors about 14 million inhabitants and over 6,000 industries, including two large petrochemical plants, emitting heavy loads to the atmosphere. Precipitation events are also due to cold fronts and annual rainfall average $1,200 \mathrm{~mm}$. The Itacuruçá site is located by Sepetiba Bay, but about $30 \mathrm{~km}$ upwind from the local industrial park, between the Serra do Mar Mountains and the Island of Itacuruçá, which allows the formation of intense orographic rains apart from the cold fronts. Annual rainfall can reach up to $2,300 \mathrm{~mm}$.

\section{Material and Methods}

Two bulk deposition samplers were installed less than $10 \mathrm{~km}$ from the sea in all sites, at least $1.5 \mathrm{~m}$ from the soil or roof surface to avoid splash water to enter the samplers.

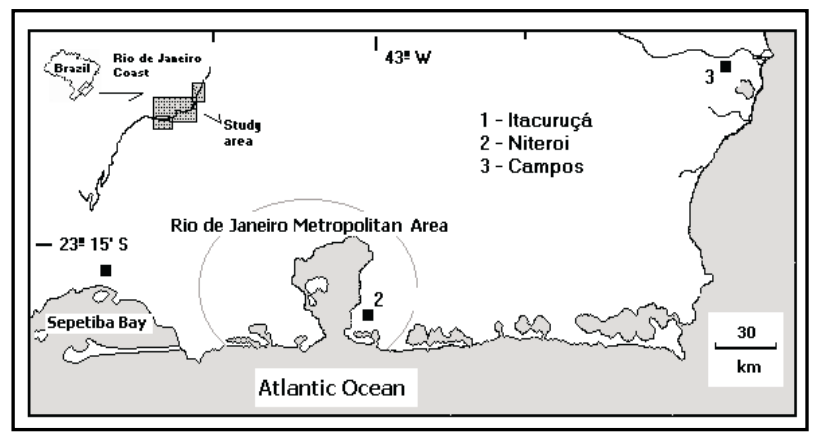

Figure 1. Map of the Rio de Janeiro coast showing sampling sites
Samplers were made of permanently open Teflon funnels and tubes and samples were collected in pre-cleaned Teflon bottles and frozen for transport. These bulk deposition samplers contain $100 \%$ of the wet deposition and whatever dry deposition collected in the funnels and is rinsed into the receiving bottle. ${ }^{9}$ We used un-acidified Teflon bottles deployed from $6 \mathrm{~h}$ to 28 days, depending on precipitation volume. An intensive study exercise on methods comparison for measuring $\mathrm{Hg}$ in rainfall $^{10}$ showed no difference in $\mathrm{Hg}$ content of bulk atmospheric deposition collected in pre-acidified or un-acidified bulk deposition samples, during deployments of up to 35 days. Since our deployment periods were always less than the limit established by this study, ${ }^{10}$ contamination or loss of $\mathrm{Hg}$ due to this variable were unlikely.

Open collectors deployed for longer periods of time tend to collect relatively more dry-deposition than shortperiod deployments, and may result in systematically higher $\mathrm{Hg}$ concentrations. ${ }^{11}$ By using relatively short deployment times our results show no relationship between deployment period and $\mathrm{Hg}$ concentrations (Figure 2), although it does underestimate the total $\mathrm{Hg}$ concentrations in the atmospheric deposition, by minimizing the effect of dry particle deposition. Also, evidence exists showing no difference between bulk and wet $\mathrm{Hg}$ concentrations and fluxes for short deployment periods, suggesting the small importance of the dry deposition component of the bulk data for short deployment periods. ${ }^{9}$

Sample volume ranged from a minimum of about $200 \mathrm{~mL}$ to over $2 \mathrm{~L}$. In $60 \%$ of the samples more than one bottle was filled during deployment. We analyzed all bottles from any event separately and an average concentration for those sampling periods was recorded. Differences among bottles range widely, since the beginning of rain is frequently enriched relative to the end of the rain period. ${ }^{11}$ Variation in $\mathrm{Hg}$ concentrations among bottles of a single event averaged $30 \%$. All samples were immediately analyzed, in duplicate, after collection (within $48 \mathrm{~h}$ maximum).

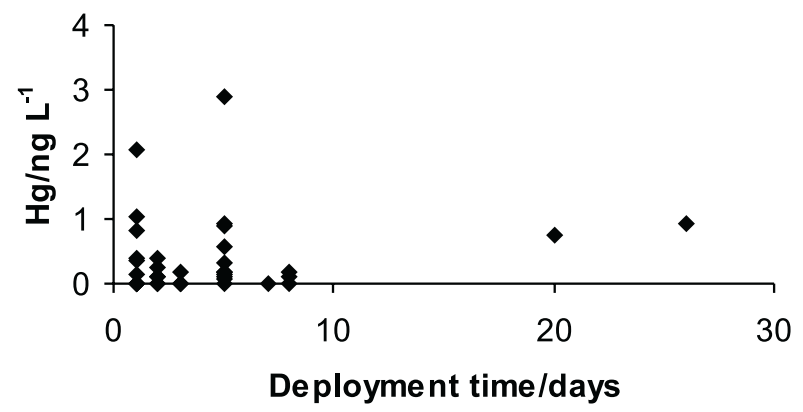

Figure 2. Relationship between mercury concentrations and deployment periods of samplers for all sampling sites along the coast of Rio de Janeiro State, Southeast, Brazil 
Total $\mathrm{Hg}$ was determined after oxidation with $0.2 \mathrm{~mL}$ of a bromine monochloride solution $\left(0.1 \mathrm{~mL} \mathrm{KBrO}_{3}\right.$ $1 \% \mathrm{~m} / \mathrm{v}+0.1 \mathrm{~mL} \mathrm{HCl} 20 \% \mathrm{v} / \mathrm{v})$. After oxidation, $0.1 \mathrm{~mL}$ of $1 \% \mathrm{~m} / \mathrm{v}$ ascorbic acid solution was used to reduce the excess $\mathrm{BrCl}$, this was followed by a reduction with $1.0 \mathrm{~mL}$ of acidic $\left(2.6 \mathrm{~mol} \mathrm{~L}^{-1} \mathrm{HCl}\right) 1.0 \% \mathrm{~m} / \mathrm{v} \mathrm{SnCl}_{2}$ solution. ${ }^{4}$ The $\mathrm{Hg}^{0}$ resultant from the reduction reaction was purged from the sample with $\mathrm{Hg}$-free Argon, at a flow rate of $40 \mathrm{~mL} \mathrm{~min}^{-1}$, for $3 \mathrm{~min}$, and collected on a gold wool trap connected to the outlet of the reaction vessel. Two Au traps in the gas line stripped any $\mathrm{Hg}$ from the carrier gas. All connecting tubing was made of Teflon with glass-Teflon connections made of clean silicone tubing. Mercury determination was performed at a wavelength of $253.7 \mathrm{~nm}$, in a Tekran Model 2500 Cold Vapor Atomic Fluorescence Spectrophotometer. ${ }^{12}$ Under the operational conditions described, the analytical detection limit of the method, based on three standard deviations of the average $\mathrm{Hg}$ concentrations of the reagents blank, was $0.02 \mathrm{ng} \mathrm{L}^{-1}$. All samples were analyzed in duplicate. Differences between duplicates remained below $15 \%$ for all samples. The extraction method used oxidizes all dissolved $\mathrm{Hg}$ in the sample but do not release $\mathrm{Hg}$ eventually present in deposited atmospheric particles, i.e. no digestions of samples were performed.

\section{Results and Discussion}

Table 1 summarizes the $\mathrm{Hg}$ concentrations measured in bulk atmospheric deposition collected in the three sites while Figure 3 shows its temporal variability. At the Itacuruçá site $\mathrm{Hg}$ concentrations were lowest with average concentrations of $0.24 \mathrm{ng} \mathrm{L}^{-1}(\mathrm{n}=19)$, ranging from a maximum concentration per event of $1.04 \mathrm{ng} \mathrm{L}^{-1}$ to a minimum of $<0.02 \mathrm{ng} \mathrm{L}^{-1}$. Maximum concentration in a single bottle reached $2.08 \mathrm{ng} \mathrm{L}^{-1}$. At this site $35 \%$ of the samples showed $\mathrm{Hg}$ concentrations below the detection limit of the method. This is probably a result of the very short deployment times of this sampling resulting in very small effect of particle deposition. Since at this site sampling period was only of 3 months, no temporal distribution trend could be detected (Figure 3). Eventual changes in dominant wind direction from SW to NE may bring $\mathrm{Hg}$ from the Sepetiba Bay industrial park, and this may be responsible for the two peaks observed in early November. Marins et al. ${ }^{4}$ showed very high $\mathrm{Hg}$ concentrations in bulk atmospheric deposition close to and downwind from the Sepetiba Bay industrial park and using long deployment times. They measured concentrations ranging from 30 to $164 \mathrm{ng} \mathrm{L}^{-1}$ closer to industrial point sources, and associated these high values with the washout of $\mathrm{Hg}$-rich particles. This has also been shown to occur in urban centers close to gold dealer shops where gold smelting at high temperatures emits $\mathrm{Hg}$-rich particles. ${ }^{5,6}$ Particulate emissions however, seldom spread too much long distance, as have been shown for many types of point sources. ${ }^{5}$ Therefore, at Itacuruçá, the position of the sampling site relative to winds and the dominance of orographic rains in the atmospheric deposition result in very low $\mathrm{Hg}$ concentrations.

At the Campos dos Goytacazes site, average concentrations were twice those measured at Itacuruçá $\left(0.51 \mathrm{ng} \mathrm{L}^{-1}\right.$, $\mathrm{n}=15$ ). Maximum concentration per event reached $1.01 \mathrm{ng} \mathrm{L}^{-1}$ and minimum of $0.07 \mathrm{ng} \mathrm{L}^{-1}$. Peak concentration in a single bottle reached $1.85 \mathrm{ng} \mathrm{L}^{-1}$. The distribution of $\mathrm{Hg}$ concentrations suggests a seasonal trend, with higher concentrations occurring during the dry season, particularly from March to May and in August and September (Figure 3). During these samplings, bottles frequently presented soot and coal particles, suggesting an influence of the pre-harvest burning of the sugar cane plantations. No sample showed $\mathrm{Hg}$ concentrations below the detection limit of the method.

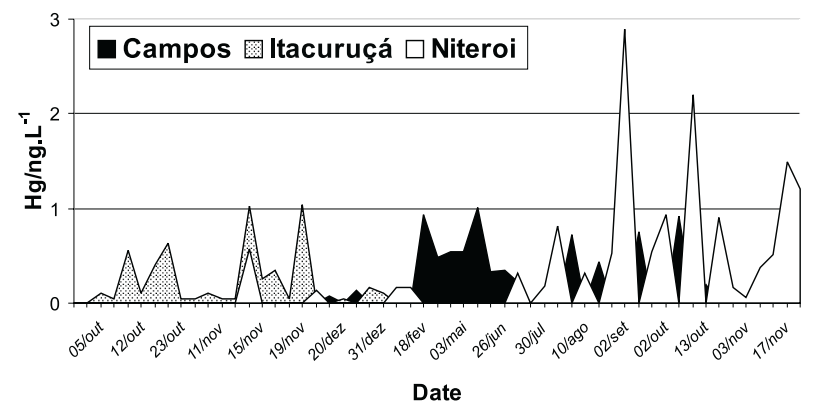

Figure 3. Mercury concentrations in bulk atmospheric deposition in three different sites along the coast of Rio de Janeiro State, Southeast, Brazil. Samples from Itacuruça with concentrations below the detection limit are plotted as equal to the detection limit (0.02 $\left.\mathrm{ng} \mathrm{L}^{-1}\right)$, to avoid confusion with dates without sampling

Table 1. Summary of $\mathrm{Hg}$ concentrations $\left(\mathrm{ng} \mathrm{L}^{-1}\right)$ in bulk precipitation from three sampling sites along the Rio de Janeiro coast, Southeast, Brazil

\begin{tabular}{lccc}
\hline Site & $\begin{array}{c}\text { Range of concentrations } \\
\text { in individual bottles }\end{array}$ & $\begin{array}{c}\text { Range of concentrations } \\
\text { in deployment periods }\end{array}$ & $\begin{array}{c}\text { Average concentration } \\
\text { per deployment period }\end{array}$ \\
\hline Itacuruçá & $<0.02-2.08$ & $<0.02-1.04$ & 0.24 \\
Campos & $<0.02-1.85$ & $0.07-1.01$ & 0.51 \\
Niterói & $0.06-4.3$ & $0.06-2.95$ & 0.73 \\
\hline
\end{tabular}


Sugar cane agriculture may contribute with atmospheric $\mathrm{Hg}$ emissions due to the burning of bagasse at sugar mills and pre-harvest burning in the field, typical of this type of agriculture. Also, during pre-harvest burning, significant emissions of $\mathrm{Hg}$ may happen from soils through vaporization, ${ }^{13}$ in particular in areas where organo-mercurials were used as fungicides in seedling protection, a common practice in Campos dos Goytacazes sugar cane agriculture until 1980, when it was banned by federal law. ${ }^{14}$

A comparable study in Florida everglades sugar cane area, where no $\mathrm{Hg}$ containing chemicals were ever used notwithstanding, showed that pre-harvest burning is the most significant source of $\mathrm{Hg}$ and that volatilization from soils is negligible. ${ }^{13}$

At Niterói, Hg concentrations were highest, with an event average of $0.73 \mathrm{ng} \mathrm{L}^{-1}$. Maximum event concentrations reached $2.95 \mathrm{ng} \mathrm{L}^{-1}$ and minimum of $0.06 \mathrm{ng} \mathrm{L}^{-1}$. Peak concentration in individual bottles reached $4.3 \mathrm{ng} \mathrm{L}^{-1}$ and no sample presented $\mathrm{Hg}$ concentrations below the detection limit of the method. No seasonal trend was observed, although high frequency of maximum concentration peaks occurred mostly between September and October (Figure 3). These peaks are probably associated with events of high atmospheric emissions from the industrial park of Rio de Janeiro metropolitan area. No significant point source of $\mathrm{Hg}$ exists in the region. However, many industries have $\mathrm{Hg}$ as a component of their atmospheric effluent, in particular oil refineries and iron and steel plants. Therefore $\mathrm{Hg}$ emissions are quite variable in time and space, being dependent on type of raw material used (e.g. iron ore vs. scrap metal in steel plants, or the origin of the oil burnt in a refinery). Thus seasonal patterns are frequently absent from this type of emission. Clearly, however, the concentrations obtained in Niteroi show the influence of the industrial metropolitan area of Rio de Janeiro, with average values nearly 4 and 2 times higher than those found at Itacuruçá and Campos, respectively.

Table 2 compares the results found along the Rio de Janeiro coast with recent values reported in the literature for the northern hemisphere. Notwithstanding the relative high concentrations measured at Niterói, bulk atmospheric deposition along the coast of Rio de Janeiro shows much lower $\mathrm{Hg}$ concentrations than other coastal sites in the northern hemisphere (Table 2). Even considering peak bottle concentrations, our values are in the lower range of those reported for the northern hemisphere and are much lower than those reported for areas close to point sources of $\mathrm{Hg}$. The lack of significant point sources of $\mathrm{Hg}$ and the strong influence of marine air masses over the sampling sites are probably the major reasons for this result.

As stated before, reliable daily precipitation volume data for the sites are not available. Historical precipitation data for the regions where the sites were located, however, do exist and allow at least a preliminary estimate of the order of magnitude of the atmospheric $\mathrm{Hg}$ deposition, at least on a yearly basis. This is obviously an underestimation since for properly assessing $\mathrm{Hg}$ atmospheric deposition, a longer; at least one year-period of deployment would be necessary. Notwithstanding, taking into consideration this limiting aspects and considering average concentrations per deployment period (Table 1), bulk atmospheric deposition would range from about $0.4 \mu \mathrm{g} \cdot \mathrm{m}^{-2} \cdot \mathrm{yr}^{-1}$ at the more pristine site of Itacuruçá to about $3.3 \mu \mathrm{g} \mathrm{m}^{-2} \mathrm{yr}^{-1}$, at Niteroi. As expected these values compare well with the lower range of wet deposition values for continental sites in the northern hemisphere during the 1900 's decade, ${ }^{13,15-17}$ which ranged from about 5 to $11 \mu \mathrm{g} \mathrm{m}^{-2} \mathrm{yr}^{-1}$, and present-day deposition estimated for remote sites in northern South America, ${ }^{18}$ but are at least one order of magnitude lower than values found close to point sources, ${ }^{4-6,19}$ where a significant contribution of dry deposition and washed out particles characteristically results in elevated bulk atmospheric deposition rates.

Regarding the possible contamination of receptor environments, the estimates of atmospheric deposition based on this limited set of data, shows that although fairly low compared to the northern hemisphere, deposition rates estimated here can be 2 to 3 times higher than background deposition over remote areas in the open South Atlantic Ocean, which typically range from $0.13 \mu \mathrm{g} \mathrm{m}^{-2} \mathrm{yr}^{-1}$ around Antarctica to $4.1 \mu \mathrm{g} \mathrm{m}^{-2} \mathrm{yr}^{-1}$ at mid latitudes ${ }^{20,21}$ and twice pre-industrial values measured in the Amazon region, ${ }^{18}$ suggesting that at least for the agricultural region of Campos and the urban-industrial site at Niterói, notwithstanding being far from $\mathrm{Hg}$ point sources, surface ecosystems are already submitted to anomalous high deposition rates of $\mathrm{Hg}$, exposing their biota to anomalous high $\mathrm{Hg}$ levels.

Table 2. Mercury concentrations in bulk atmospheric deposition over Rio de Janeiro State coast compared with other industrial and remote sites

\begin{tabular}{ll} 
Location & $\mathrm{Hg}\left(\mathrm{ng} \mathrm{L}^{-1}\right)$ \\
\hline Southern Sweden coast & $10.6-13.8$ \\
Southern Florida, USA $^{13}$ & $15-23$ \\
Northwestern Ontario, Canada $^{17}$ & $0.95-9.31(4.04)$ \\
Midwest USA $^{15}$ & $4.3-28.9(14.3)$ \\
Oak Ridge, Tennessee, USA $^{11}$ & $7.6-17.4(11.5)$ \\
Wisconsin, USA $^{15}$ & $3.2-15.2(10.5)$ \\
Cheasapeak bay, USA $^{19}$ & $<2.0-80(17)$ \\
Northern South America $^{18}$ & $2.6-11.4$ \\
Over the Central Pacific Ocean & \\
Itacuruçá, Northern Sepetiba Bay, & $<2.0$ \\
Southern Rio de Janeiro coast & $<0.02-2.08(0.24)$ \\
Campos dos Goytacazes, Northern & $<0.02-1.85(0.51)$ \\
Rio de Janeiro coast & \\
Niterói, metropolitan Rio de Janeiro & $0.06-4.3(0.73)$ \\
\hline
\end{tabular}


Vol. 13, No. 2, 2002 Mercury Concentrations in Bulk Atmospheric Deposition over the Coast of Rio de Janeiro

\section{Acknowledgements}

This study is part of a PRONEX project coordinated by LDL supported by the Ministry of Science and Technology of Brazil.

\section{References}

1. Fitzgerald, W.F.; Engstrom, D.E.; Mason, R.P.; Nater, E.A.; Environm. Sci. Technol. 1998, 32, 1.

2. Lacerda, L.D.; Ciênc. Cult. 1997, 49, 54.

3. Rolfhus, K.R.; Fitzgerald, W.F.; Water Air Soil Pollut. 1995, $80,291$.

4. Marins, R.V.; Silva Filho, E.V.; Lacerda, L.D.; J. Braz. Chem. Soc. 1996, 7, 3 .

5. Marins, R.V.; Andrade, J.B.; Pereira, P.A.P.; Paiva, E.C.; Paraquetti, H.H.M.; J. Environ. Monit .2000, 2, 325.

6. Lacerda, L.D.; Salomons, W.; Mercury from Gold and Silver Mining: A Chemical Time-bomb?, Springer Verlag: Berlin, 1998, p146.

7. Silva Filho, E.V.; Paiva, R.P.; Wasserman, J.C.; Lacerda, L.D.; J. Braz. Chem. Soc. 1998, 9, 482.

8. Secretaria de Estado de Meio Ambiente e Desenvolvimento Sustentável do Estado do Rio de Janeiro; Subsídios para Gestão dos Recursos Hídricos das Bacias Hidrográficas dos Rios Macacu, São João, Macaé e Macabu, Rio de Janeiro, 1999. (ISBN - 85-87206-03-6).

9. Guentzel, J.L.; Landing, W.M.; Gill, G.A.; Pollman, C.D.; Water Air Soil Pollut. 1995, 80, 393.
10. Landing, W.M.; Guentzel, J.L.; Gill, G.A.; Pollman, C.D.; Atmos. Environm. 1998, 32, 909.

11. Lindberg, S.E.; Owens, J.G.; Straton, W.J. In: Mercury Pollution: Integration and Synthesis. Watras, C.J.; Huckabee, J.W. eds.; Lewis Publ.: Boca Raton, 1994, p 261.

12. Marins, R.V.; Paraquetti, H.H.M.; Ayres, G.A.; Quimica Nova 2001, in press.

13. Patrick, W.H.; Gambrell, R.P.; Parkplan, P.; Tau, F. In: Mercury Pollution: Integration and Synthesis. Watras, C.J.; Huckabee, J.W. eds.; Lewis Publ.: Boca Raton, 1994, p 609.

14. Camara, V.M.; Cadernos de Saúde Pública. 1986, 2, 359.

15. Glass, G.E.; Sorensen, J.A.; Environm. Sci. Technol. 1999, 33, 3303.

16. Munthe, J.; Hultberg, H.; Iverfeldt, A.; Water Air Soil Pollut. 1995, 80,363 .

17. St Louis, V.L.; Rudd, J.W.M.; Kelly, C.A.; Barrie, L.A.; Water Air Soil Pollut. 1995, 80, 405.

18. Lacerda, L.D.; Ribeiro, M.G.; Cordeiro, R.C.; Sifeddine, A.; Turcq, B.; Ci. Cult. J. Braz. Ass. Adv. Sci. 1999, 51, 363.

19. Mason, R.P.; Lawson, N.M.; Sullivan, K.A.; Atmos. Environm. 1997, 21, 3541 .

20. Fitzgerald, W.F.; Mason, R.P.; Vandal, G.M.; Water Air Soil Pollut. 1991, 56, 745.

21. Ebinghaus, R.; Tripathi, R.M.; Wallshlager, D.; Lindberg, S.E. In: Mercury Contaminated Sites; Ebinghaus, R.; Turner, R.R.; Lacerda, L.D.; Vasiliev, O.; Salomons, W. eds.; Springer Verlag: Heidelberg, 1999, p 3.

Received: April 26, 2001

Published on the web: January 28, 2002 